LAPORAN KASUS

\title{
Tatalaksana Komplikasi Tromboemboli pada Pasien Terkonfirmasi Corona Virus Disease-19
}

\section{Management of Thromboembolic Complications in Confirmed Corona Virus Disease -19 Patients}

\author{
Alfian Aditia ${ }^{{ }^{*}}$, Mahendratama Purnama Adhi, Bagus Fajar Rohman, Oky Susianto, \\ Erna Kusumawardhani ${ }^{* *}$ \\ "Departemen Anestesiologi dan Terapi Intensif, Fakultas Kedokteran, Universitas Lambung \\ Mangkurat/RSUD Ulin, Banjarmasin, Indonesia \\ ${ }^{* *}$ Departemen Pulmonologi dan Kedokteran Respirasi, Fakultas Kedokteran, Universitas \\ Lambung Mangkurat/ RSUD Ulin, Banjarmasin, Indonesia \\ ${ }^{\boxplus}$ Korespondensi: alfiansinagaa@gmail.com
}

\begin{abstract}
Background: Corona Virus Disease-19 (COVID-19) as pandemic disease can cause thromboembolism as one the complication triggered by coagulopathy condition with incidence rate between 16.5\%-21\%. Coagulopathy is the causes of this complication. One mechanism of coagulopathy in COVID-19 patients is caused by an inflammatory process. Increased inflammatory factors, coagulation factors, and clinical scoring were used as predictors of thromboembolic complications. The anticoagulant can prevent these complications.

Case report: A male, 43 years old, COVID-19 confirmed with a PADUA score $=4$, increase in D-dimers and have given anticoagulant prophylactic. After 14 days of treatment patient becames dyspnea, tachycardia and hypoxemia. Humpton's hump was showed in chest $x$-rays and electrocardiography (ECG) shows image of S1Q3T3 pattern and corrected QT interval (QTc) of 552 mms. Patient was managed with mechanical ventilation and therapeutic doses of unfractionated heparin (UFH). When sedation being stopped, the patient had hemiparalysis on the left side.

Discussion: Clinical manifestation of pulmonary embolism (PE) are dyspnea / tachypnea, tachycardia, cyanosis, hemoptysis, hypoxemia with acute onset. Based on severity, PE divided into massive, sub-massive, low risk. The appearance of a Humpton's hump on the chest X-ray use for suspected of pulmonary embolism. Computed tomography pulmonary angiogram (CTPA) examination is the standard diagnosis, but ECG can be used as a modality for suspected embolism with tachycardia / tachyarrhythmias, S1Q3T3 pattern and prolonged QTc interval. Administration anticoagulants as thromboprophylaxis still can't prevent thromboembolic complication and ischemic stroke can occur, but PE known as the most common complication of thromboembolism in patient with COVID-19.
\end{abstract}


Conclusion: Clinical evaluation, routine ECG and D-dimer levels can be consideration for Thromboprophylaxis procedure and can be a strategy for early screening for the risk of thromboembolic complications. In COVID-19 patients with critical degree should be considered giving more aggressive anticoagulants and using therapeutic doses.

Keyword: COVID-19; pulmomary embolism; stroke; thromboembolism; thromboprophylaxis

\begin{abstract}
ABSTRAK
Latar Belakang: Corona Virus Disease-19 (COVID-19) merupakan penyakit pandemi yang dapat menyebabkan komplikasi tromboemboli sebagai akibat terjadinya koagulopati dengan insidensi sekitar $16.5-21 \%$. Salah satu patofisiologi koagulopati pada pasien COVID-19 disebabkan oleh proses inflamasi. Peningkatan faktor inflamasi, faktor koagulasi, dan skoring klinis digunakan sebagai prediksi terjadinya komplikasi tromboemboli. Pemberian antikoagulan memiliki peran untuk mencegah terjadinya komplikasi tersebut.
\end{abstract}

Kasus: Pasien laki-laki, 43 tahun, positif COVID-19 dengan skor PADUA $=4$, peningkatan D-dimer dan mendapatkan terapi profilaksis antikoagulan. Dalam perawatan hari ke-14, sesak napas memberat, takikardi dan hipoksemia dialami pasien. Didapatkan gambaran Humpton's hump pada foto toraks dan gambaran elektrokardiography (EKG) pola S1Q3T3 dan corrected QT interval (QTc) $552 \mathrm{mms}$. Penatalaksanaan pasien dengan ventilasi mekanik dan terapi unfractionated heparin (UFH) dosis terapeutik. Saat pasien bebas dari sedasi, ditemukan kelemahan tubuh bagian kiri.

Diskusi: Gejala klinis emboli paru umumnya berupa dispnea/takipnea, takikardi, sianosis, hemoptisis, hipoksemia dengan onset akut. Berdasarkan keparahannya, dibagi menjadi masif, sub-masif, risiko rendah. Gambaran Humpton's hump pada foto toraks dapat menjadi dugaan terjadi emboli paru. Pemeriksaan computed tomography pulmonary angiogram (CTPA) merupakan standar diagnosisnya, namun EKG dapat digunakan sebagai modalitas kecurigaan emboli dengan gambaran takikardi/takiaritmia, pola S1Q3T3 dan pemanjangan interval QTc. Pemberian antikoagulan sebagai tromboprofilaksis tetap tidak dapat mencegah terjadinya komplikasi tromboemboli seperti terjadinya stroke iskemik, tetapi emboli paru merupakan komplikasi tromboemboli yang paling sering terjadi.

Kesimpulan: Evaluasi klinis, EKG secara rutin dan kadar D-dimer dapat menjadi pertimbangan dalam pemberian tromboprofilaksis dan dapat menjadi strategi penapisan awal risiko komplikasi tromboemboli. Pada pasien COVID-19 derajat kritis perlu dipertimbangkan pemberian antikoagulan yang lebih agresif dan menggunakan dosis terapeutik.

Kata Kunci: COVID-19; emboli paru; stroke; thromboprofilaksis; tromboemboli 


\section{PENDAHULUAN}

COVID-19 pertama kali dilaporkan di Wuhan, China pada Desember 2019. Dalam waktu dua bulan, COVID-19 dengan cepat menyebar ke seluruh dunia. Pada tanggal 11 Maret 2020 World Health Organization (WHO) menetapkan COVID-19 sebagai wabah pandemi. ${ }^{1}$

Beberapa penelitian menunjukkan kejadian outbreak berhubungan dengan meningkatnya risiko terjadinya trombosis. Koagulopati menjadi salah satu penyebab terjadinya thrombosis. Proses koagulopati yang terjadi pada pasien COVID-19 memiliki peran yang cukup dominan dalam mortalitas dan morbiditas, prognosis yang kurang baik dan ditimbulkan dari berbagai jalur mekanisme koagulopati yang cukup kompleks. Proses inflamasi yang terjadi dengan badai sitokin dan cedera paru yang diakibatkan oleh infeksi SARSCoV-2 pada pasien COVID-19. Sebuah penelitian di Italia, melaporkan kejadian tromboemboli vena sekitar $21 \%$ pada 388 pasien COVID-19 yang dirawat di rumah sakit, dengan data stroke iskemik sebesar 2,5\%. ${ }^{2}$ Presentase ini lebih besar pada pasien yang dirawat di intensive care unit (ICU) 27,6\% dibandingkan di ruang perawatan biasa $6.6 \%$. Penelitian lain pada 150 pasien COVID-19 juga melaporkan kejadian emboli paru sekitar 16.5\%. ${ }^{3}$ Anastasios dkk. menunjukkan bahwa derajat penyakit COVID-19 yang berat dapat menyebabkan terjadinya komplikasi berupa gangguan koagulopati dengan karakter protrombotik yang meningkatkan risiko terjadinya tromboemboli vena. ${ }^{4}$

Salah satu cara untuk menilai terjadinya proses koagulasi pada pasien COVID-19 dengan melakukan pemeriksaan Ddimer. Peningkatan kadar D-dimer menggambarkan aktivasi dari sistem koagulasi dan fibrinolisis yang sedang berlangsung. ${ }^{5}$ Pada pasien COVID-19, sebagian besar mengalami peningkatan kadar D-dimer $2-3$ kali dari nilai normal. Penelitian awal di China melaporkan peningkatan D-dimer $>0,5$ $\mathrm{mcg} / \mathrm{ml}$ terjadi pada $46 \%$ pasien, serta terdapat tanda-tanda aktivasi faktor koagulasi seperti trombositopenia ringan dan pemanjangan waktu protrombin. ${ }^{6}$ Selanjutnya, Fei Zhou dkk, dalam penelitiannya menyatakan, pasien dengan kadar D-dimer > 1,0 $\mathrm{mcg} / \mathrm{ml}$ memiliki risiko kematian 18 kali lipat. ${ }^{7}$ Moore memberikan prediksi sebesar 94\% pasien COVID-19 tidak mengalami komplikasi tromboemboli bila kadar Ddimer $<1 \mu \mathrm{g} / \mathrm{ml}^{8}{ }^{8}$

Pemeriksaan D-dimer memiliki sensitivitas yang tinggi tetapi spesifisitasnya rendah. Kadar D-dimer tidak dapat digunakan sebagai satusatunya parameter prediksi terjadinya deep vein thrombosis (DVT)/emboli paru. $^{5}$ Risiko terjadinya komplikasi tromboemboli vena juga dapat diprediksi dengan menggunakan beberapa sistem nilai prediksi. Nilai prediksi PADUA memperkirakan risiko terjadinya komplikasi tromboemboli dengan mengkalkulasikan beberapa faktor, yaitu riwayat tromboemboli vena sebelumnya, penyakit keganasan, pengurangan mobilitas, trombofilia, adanya trauma atau pembedahan, usia $\geq 70$ tahun, gagal napas/jantung, infark miokard akut/stroke, infeksi akut, obesitas, sedang dalam terapi hormonal. Nilai PADUA $<4$ memiliki risiko rendah, sedangkan nilai PADUA $\geq 4$ berisiko tinggi mengalami tromboemboli vena. Dengan menggunakan penilaian PADUA, Zhai Z dkk melaporkan $40 \%$ pasien COVID-19 yang mendapatkan perawatan, berisiko tinggi mengalami komplikasi tromboemboli vena. ${ }^{9,10}$ 
Pemberian terapi profilaksis saat ini penting dalam mencegah kejadian tromboemboli. Penelitian di beberapa negara yang menerapkan pemberian terapi profilaksis menunjukkan hasil yang memuaskan meskipun beberapa data tetap dilaporkan kejadian tromboemboli vena maupun arteri pada pasien yang telah diberikan terapi profilaksis ini. Seperti halnya penelitian di Perancis, terhadap 26 pasien COVID19 yang dirawat di ICU, melaporkan kejadian venous thromboembolism (VTE) sebesar 69\% pada semua pasien yang telah diberikan terapi tromboprofilaksis menggunakan low molecular weight heparin (LMWH). ${ }^{11}$ Berdasarkan hal tersebut, kami melaporkan kasus pasien COVID-19 yang di rawat di ruang ICU dengan kecurigaan mengalami komplikasi tromboemboli paru dan stroke iskemik yang sebelumnya telah mendapat terapi tromboprofilaksis.

\section{KASUS}

Laki-laki usia 43 tahun dengan obesitas kategori 1 (IMT 30) pekerjaan sebagai petugas pemulasaran pasien COVID-19, masuk rumah sakit dengan keluhan batuk, demam dan sesak napas yang telah dialami selama 4 hari. Pasien merasakan nafsu makan yang mulai berkurang, tidak ditemukan gejala anosmia. Pasien memiliki komorbid penyakit hipertensi dan diabetes mellitus yang tidak terkontrol. Penilaian dengan menggunakan PADUA didapatkan nilai 4 (obesitas $=1$; bed rest $>3$ hari $=3$ ). Pasien terkonfirmasi COVID-19 berdasarkan pemeriksaan apusan dengan metode polymerase chain reaction (PCR).

Pasien telah mendapat perawatan di ruang isolasi selama 4 hari dengan terapi protokol COVID-19 berdasarkan WHO. Hari pertama perawatan di ruang isolasi, didapatkan D-dimer $0.23 \mathrm{mcg} / \mathrm{ml}$ yang kemudian meningkat menjadi 0,58 $\mathrm{mcg} / \mathrm{ml}$. Pasien dikonsulkan untuk perawatan ICU karena sesak napas yang memberat, saturasi oksigen $68 \%$ dengan high flow nasal canul (HFNC) flow 60 lpm $\mathrm{FiO}_{2} 80 \%$ dan hasil analisa gas darah (AGD) menurut kriteria BERLIN dikategorikan sebagai severe acute respiratory distress syndrome (ARDS), dimana $P / F$ ratio 51 . Di ruang ICU, pasien mendapatkan terapi oksigen menggunakan HFNC dengan flow 60 lpm, $\mathrm{FiO}_{2} \quad 90 \%$ dan ditambahkan pemberian anti koagulan profilaksis heparin dosis 2 x 5000 IU subcutan (SC) serta terapi tambahan anti interleukin-6 (IL-6) tocilizumab $800 \mathrm{mg}$ dengan dua dosis terbagi. Hari perawatan ke-12, pasien berhasil dilakukan penyapihan HFNC, dan terapi oksigen dilanjutkan dengan nasal kanul $3 \mathrm{lpm}$. Hari perawatan ke-14, pasien dipindahkan ke ruang perawatan isolasi. Namun, $2 \mathrm{jam}$ di ruang perawatan isolasi, pasien mengalami sesak napas, dengan frekuensi napas 32-45x/menit, saturasi oksigen 58\% dengan non-rebreathing mask (NRM) 15 lpm, gelisah serta gerakan involunter ekstremitas bawah kanan. Pasien dipindahkan kembali ke ICU dengan hipoksemia, penurunan kesadaran, peningkatan tekanan darah, takikardi, takipnea dan desaturasi. Diputuskan dilakukakan tindakan intubasi dan pemasangan ventilator mode PC-Bipap $\mathrm{FiO}_{2} 100 \%$ dengan pressure inspiration 28, I:E rasio 1:1.3, respiratory rate $(\mathrm{RR}) 26 \mathrm{x} / \mathrm{i}$, positive end expiratory pressure (PEEP) 13, pressure support 25, didapatkan $\mathrm{SpO}_{2} 82 \%$. Lini masa selama perawatan dapat dilihat di Tabel 1. 
Tabel 1. Lini mas selama ruang perawatan

\begin{tabular}{|c|c|c|c|c|}
\hline & Ruang isolasi & & ICU & \\
\hline & HP-1 & HP-7 & HP-12 & HP-14 \\
\hline Respirasi & $\begin{array}{l}\text { napas spontan RR } \\
28 \mathrm{x} / \text { menit, Rh-/- } \\
\mathrm{SpO}_{2} 88 \% \text { HFNC } \\
\mathrm{FiO}_{2} 90 \% \text { flow } 60 \\
\text { lpm } \\
\text { Indeks ROX } 3.49\end{array}$ & 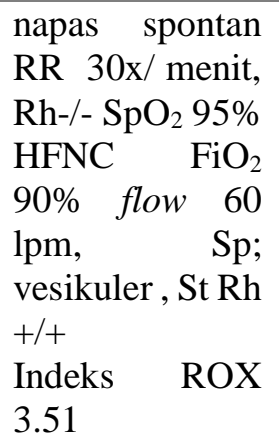 & 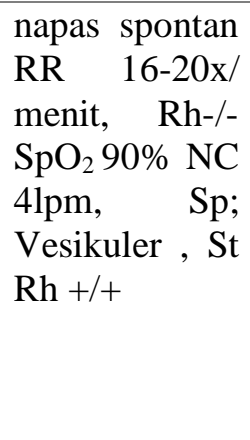 & $\begin{array}{l}\text { on venti } \\
\text { pc bipap } \mathrm{FiO}_{2} \\
100 \% \text { tv : } 934 \mathrm{i} \\
: \text { e } 1: 1.3 \mathrm{rr}: 26 \\
\text { peep : } 13 \text { ps }: \\
25 \text { p.insp : } 28, \\
\mathrm{SpO}_{2} 85 \%\end{array}$ \\
\hline Kardiovaskular & $\begin{array}{l}\text { TD 144/86 mmhg, } \\
\text { N 110x/menit }\end{array}$ & $\begin{array}{lr}\text { TD } & 122 / 78 \\
\text { mmhg, } & \mathrm{N} \\
88 \mathrm{x} / \mathrm{menit} & \end{array}$ & $\begin{array}{l}\text { TD } 102 / 78 \\
\text { mmhg, } \\
\text { N 122x/menit }\end{array}$ & $\begin{array}{l}\text { TD } 116 / 66 \\
\mathrm{mmhg}, \\
\mathrm{N} \mathrm{140x/menit,} \\
\text { iregular }\end{array}$ \\
\hline
\end{tabular}

Setelah prosedur intubasi dan pemasangan ventilator, pada monitor pasien didapatkan irama jantung takiaritmia dengan heart rate (HR) 150 $\mathrm{x} / \mathrm{menit}$. Pasien diterapi dengan amiodarone kontinyu intra vena (IV) dilanjutkan dengan pemberian oral. Gambaran EKG setelah pemberian amiodarone memperlihatkan sinus takikardi, pola S1Q3T3 dan pemanjangan interval QTc. Namun tidak ditemukan gambaran inversi gelombang $\mathrm{T}$ anteroseptal. Sehari setelahnya, gambaran EKG masih sinus takikardi, terlihat pola S1Q3T3, right axis deviation, namun pemanjangan interval QT tidak ditemukan. Beta blocker (propranolol) oral diberikan untuk terapi takikardi yang menetap. Pada perawatan hari ke-19 gambaran EKG memperlihatkan sinus ritme dan tidak ditemukan lagi pola S1Q3T3. Tren perubahan EKG dapat dilihat Gambar 1.

Delapan jam terapi oksigen menggunakan ventilator pascaintubasi, pasien mengalami desaturasi yang menetap. Diputuskan untuk pemberian antikoagulan unfractionated heparin (UFH) dosis terapeutik, dengan dosis loading 7200 IU bolus iv dan dilanjutkan pemberian secara kontinyu iv dengan dosis $1600 \mathrm{IU} / \mathrm{jam}$. Pengawasan faal koagulasi dilakukan secara ketat. Dosis heparin kontinyu disesuaikan dengan nilai dari laboratorium aPTT. Pada perawatan hari ke-25 keadaan pasien mengalami perbaikan dan berhasil dilakukan ekstubasi. Pemberian terapi oksigen dilanjutkan dengan HFNC. Saat pasien terbebas dari pengaruh sedasi didapatkan kelemahan ektremitas atas dan bawah sebelah kiri, dengan kekuatan motorik $1 / 5$.

Evaluasi ronsen toraks yang dilakukan selama perawatan, gambaran progresivitas pneumonia COVID-19 terlihat jelas dan pada hari perawatan ke12 terdapat kecurigaan gambaran Hamtpon's hump, berupa lesi radiopak berbentuk baji di area perifer paru kanan. Gambaran ini sebagai diagnosis banding emboli paru. Interpretasi utama dari ronsen toraks adalah konsolidasi alveolar akibat pneumonia COVID-19. (Serial ronsen toraks dapat dilihat pada Gambar 2). 
Pada hari perawatan ke-28, pasien berhasil dilakukan penyapihan HFNC menjadi nasal kanul sebagai terapi oksigen. Selama perawatan di ICU, hemodinamik pasien pernah ditopang dengan vasopressor selama beberapa hari. Kekuatan motorik mengalami perbaikan hingga saat pasien pindah ke ruang perawatan, skor motorik
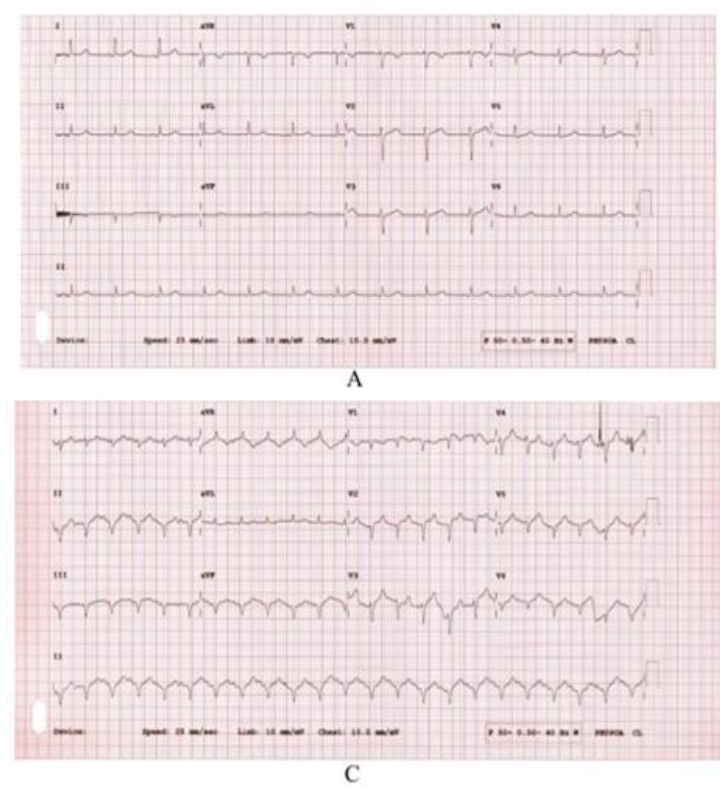

ekstremitas atas 3/5 dan ekstremitas bawah 4/5. Pasien pulang setelah mendapatkan perawatan di rumah sakit selama 53 hari. Data tren perubahan terapi oksigen, saturasi, $\mathrm{PO}_{2}, \mathrm{P} / F$ ratio, laboratorium hemoglobin, trombosit, aPTT, D-dimer, CRP dan terapi heparin, dapat dilihat pada Tabel 2 .

Gambar 1. Tren perubahan EKG sebelum dan sesudah kecurigaan komplikasi emboli paru.

A. Gambaran EKG perawatan hari ke-7 (sebelum komplikasi emboli paru), B. Gambaran EKG saat terjadi kecurigaan komplikasi emboli paru. Didapatkan sinus takikardi, pemanjangan interval QTc 552 ms dan pola S1Q3T3, C. Gambaran EKG 1 hari setelah kecurigaan komplikasi emboli paru, sinus takikardi pola S1Q3T3, right axis deviation, dan tidak ditemukan lagi pemanjangan interval QTc, D. Gambaran EKG perawatan hari ke -19, didapatkan gambaran sinus ritme. 

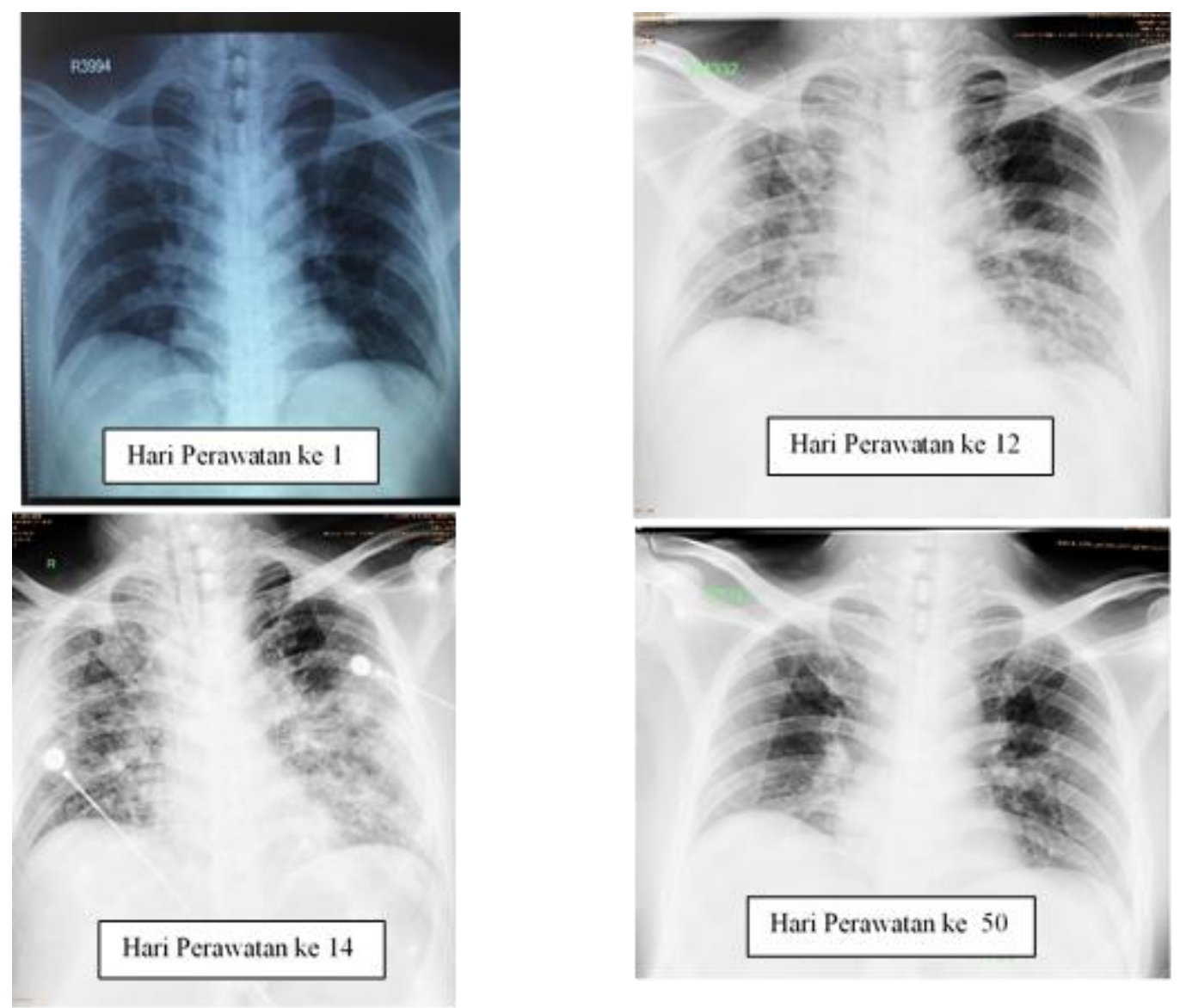

Gambar 2. Serial ronsen toraks selama perawatan.

Progresivitas pneumonia COVID-19 terlihat pada serial pemeriksaan ronsen toraks pasien. Pada hari perawatan ke-12, tampak lesi opasitas di perifer paru-paru kanan, berbentuk baji dengan permukaan cembung mengarah ke hilus (Hampton's hump). Ekspertise radiologi dari gambaran ini diarahkan pada konsolidasi alveolar akibat pneumonia COVID-19. Hari perawatan ke-14 saat komplikasi emboli paru terjadi, lesi ini terlihat jelas. Hari perawatan ke-50, gambaran lesi ini tidak ditemukan lagi. 
Tabel 2. Tren data pasien selama perawatan di RSUD Ulin Banjarmasin

\begin{tabular}{|c|c|c|c|c|c|c|c|c|c|c|c|c|c|c|c|}
\hline & H1 & H.7 & H.8 & H.9 & H.10 & H.14 & H.14 & H.15 & H.16 & H.17 & H.18 & H.21 & H. 24 & H.25 & H.28 \\
\hline $\begin{array}{l}\text { Terapi } \\
\mathrm{O}_{2}\end{array}$ & $\begin{array}{ll}\mathrm{NC} & 4 \\
\mathrm{lpm} & \end{array}$ & $\begin{array}{l}\text { HFNC } \\
601 p m \\
\mathrm{FiO}^{2} \\
81 \%\end{array}$ & $\begin{array}{l}\text { HFNC } \\
601 p m \\
\mathrm{FiO}_{2} \\
81 \%\end{array}$ & $\begin{array}{l}\text { HFNC } \\
601 p m \\
\mathrm{FiO}_{2} \\
81 \%\end{array}$ & $\begin{array}{l}\text { HFNC } \\
601 p m \\
\mathrm{FiO}_{2} \\
81 \%\end{array}$ & $\begin{array}{l}\mathrm{NC} \\
\mathrm{lpm}\end{array}$ & $\begin{array}{l}\text { On } \\
\text { venti } \\
\text { PC } \\
\text { BIPAP } \\
\mathrm{FiO}_{2} \\
100 \%\end{array}$ & $\begin{array}{l}\text { On } \\
\text { venti } \\
\text { PC } \\
\text { BIPA } \\
\mathrm{P} \\
\mathrm{FiO}_{2} \\
95 \%\end{array}$ & $\begin{array}{l}\text { On } \\
\text { venti } \\
\text { PC } \\
\text { BIPAP } \\
\mathrm{FiO}_{2} \\
90 \%\end{array}$ & $\begin{array}{l}\text { On } \\
\text { venti } \\
\text { PC } \\
\text { BIPAP } \\
\mathrm{FiO}_{2} \\
90 \%\end{array}$ & $\begin{array}{l}\text { On } \\
\text { venti } \\
\text { PC } \\
\text { BIPAP } \\
\mathrm{FiO}_{2} \\
80 \%\end{array}$ & $\begin{array}{l}\text { On } \\
\text { venti } \\
\text { PC } \\
\text { BIPA } \\
P \\
\mathrm{FiO}_{2}: \\
50 \%\end{array}$ & $\begin{array}{l}\text { On } \\
\text { venti } \\
\text { PC } \\
\text { BIPAP } \\
\mathrm{FiO}_{2} \text { : } \\
60 \%\end{array}$ & $\begin{array}{l}\text { HFNC } \\
601 p m \\
\mathrm{FiO}_{2} \\
71 \%\end{array}$ & $\begin{array}{l}\mathrm{NK} \\
31 \mathrm{pm}\end{array}$ \\
\hline $\mathrm{SpO}_{2}$ & 98 & 68 & 91 & 94 & 93 & 89 & 78 & 88 & 93 & 97 & 97 & 98 & 98 & 98 & 97 \\
\hline $\mathrm{PO}_{2}$ & 116 & 42 & 52 & 67 & 58 & 52 & 49 & 57 & 73 & 93 & 92 & 96 & 98 & 90 & 79 \\
\hline $\begin{array}{l}\mathrm{P} / \mathrm{F} \\
\text { ratio }\end{array}$ & 351,5 & 51,8 & 64,1 & 82,7 & 71,6 & 140,5 & 49 & 57 & 76,8 & 103,3 & 115 & 192 & 163,3 & 126.7 & 213 \\
\hline $\mathrm{Hb}$ & 15.6 & - & 14.1 & - & - & 15.3 & 15.2 & - & - & - & 13.6 & 13.6 & 12.8 & 12.9 & - \\
\hline $\begin{array}{l}\text { Tromb } \\
\text { osit }\end{array}$ & $\begin{array}{l}150.00 \\
0\end{array}$ & - & $\begin{array}{l}31800 \\
0\end{array}$ & - & - & $\begin{array}{l}42900 \\
0\end{array}$ & $\begin{array}{l}41400 \\
0\end{array}$ & - & - & - & $\begin{array}{l}18400 \\
0\end{array}$ & 91000 & $\begin{array}{l}52900 \\
0\end{array}$ & $\begin{array}{l}310.00 \\
0\end{array}$ & - \\
\hline aPTT & 34.2 & - & - & 24 & 31.5 & 25.9 & 51.5 & 44.2 & 65.2 & 44.9 & $>100$ & 27.1 & 25.7 & 33.8 & - \\
\hline $\mathrm{LDH}$ & 566 & - & - & 574 & - & 536 & - & - & - & - & 903 & 794 & - & 689 & - \\
\hline CRP & 48 & $<6$ & $>32$ & $>32$ & - & - & - & 1.8 & - & - & 15.7 & 50.5 & - & - & 88.2 \\
\hline $\begin{array}{l}\text { D- } \\
\text { dimers }\end{array}$ & 0.23 & - & 0.58 & - & - & - & - & - & - & - & $<0.19$ & - & - & - & - \\
\hline $\begin{array}{l}\text { Terapi } \\
\text { Hepari } \\
\text { n }\end{array}$ & - & $\begin{array}{l}\text { Inj } \\
\text { Hepari } \\
\mathrm{n} \\
2 \times 500 \\
0 \mathrm{IU}\end{array}$ & $\begin{array}{l}\text { Inj } \\
\text { Hepari } \\
\mathrm{n} \\
2 \times 500 \\
0 \mathrm{IU}\end{array}$ & $\begin{array}{l}\text { Inj } \\
\text { Hepari } \\
\text { n } \\
1 \times 500 \\
0 I U\end{array}$ & $\begin{array}{l}\text { Inj } \\
\text { Hepari } \\
\mathrm{n} \\
1 \times 500 \\
0 \mathrm{IU}\end{array}$ & $\begin{array}{l}\text { Drip } \\
\text { Hepari } \\
\text { n } 1600 \\
\text { IU/jam }\end{array}$ & $\begin{array}{l}7200 \\
\text { IU } \\
\text { bolus } \\
\text { iv } \\
\text { Drip } \\
\text { Hepari } \\
\text { n } 1600 \\
\text { IU/jam }\end{array}$ & $\begin{array}{l}\text { Drip } \\
\text { Hepari } \\
\text { n } 1000 \\
\text { IU/ja } \\
\text { m }\end{array}$ & $\begin{array}{l}\text { Drip } \\
\text { Hepari } \\
\text { n } 1000 \\
\text { IU/jam }\end{array}$ & $\begin{array}{l}\text { Drip } \\
\text { Hepari } \\
\text { n } 1000 \\
\text { IU/jam }\end{array}$ & $\begin{array}{l}\text { Drip } \\
\text { Hepari } \\
\text { n } 1000 \\
\text { IU/jam }\end{array}$ & $\begin{array}{l}\text { Inj } \\
\text { hepari } \\
\mathrm{n} \\
3 \times 500 \\
0 \mathrm{IU} \text { sc }\end{array}$ & $\begin{array}{l}\text { Inj } \\
\text { hepari } \\
\mathrm{n} \\
3 \times 500 \\
0 \text { IU sc }\end{array}$ & $\begin{array}{l}\text { Inj } \\
\text { hepari } \\
\mathrm{n} \\
3 \times 500 \\
0 \mathrm{IU} \text { sc }\end{array}$ & - \\
\hline
\end{tabular}




\section{PEMBAHASAN}

Pasien COVID-19 memiliki risiko tinggi mengalami komplikasi tromboemboli. Klok dkk, melaporkan angka kejadian komplikasi trombosis yang tinggi pada pasien COVID-19 yang mendapatkan perawatan di 3 ICU. Kejadian komplikasi trombosis sebesar 31\% tetap ditemukan walaupun terapi profilaksis trombotik telah diberikan. Dari keseluruhan kasus komplikasi tromboemboli tersebut, $87 \%$ merupakan kasus emboli paru. ${ }^{12}$

Hipotesis mengenai status hiperkoagulasi pada pasien COVID-19 berhubungan dengan saling keterkaitan antara inflamasi dan trombosis (tromboinflamasi). Inflamasi akan menyebabkan peningkatan status koagulasi yang dimediasi oleh ekspresi tissue factor (disebut juga sebagai CD142 atau faktor III). Pelepasan sitokin inflamasi menyebabkan aktivasi sel epitel, monosit dan makrofag. Peningkatan sitokin pro inflamasi (IL-1, IL-6) dan hipoksia akibat ARDS akan mengaktivasi sel endotel dan ekspresi tissue factor. Tissue factor akan memicu perubahan protrombin menjadi trombin dan selanjutnya merubah fibrinogen dalam sirkulasi menjadi fibrin dan bekuan darah. Selama kondisi inflamasi, jalur antikoagulan alami, seperti antitrombin atau jalur inhibitor tissue factor, mengalami gangguan. Keadaan ini menyebabkan status hiperkoagulasi.

Infeksi langsung SARS-CoV-2 di endotel melalui reseptor angiotensin converting enzyme (ACE-2) mengakibatkan infeksi endotel, aktivasi, dan disfungsi endotel, peningkatan ekspresi tissue factor, aktivasi platelet, serta peningkatan kadar faktor VIII dan VWF. Semua kondisi tersebut menyebabkan pembentukan trombin dan bekuan fibrin. Lebih lanjut lagi, trombin akan menyebabkan peradangan melalui efek langsung pada platelet, yang mendorong pelepasan neutrophyl extracellular traps (NETs) dari neutrophil. NETs akan mengaktivasi jalur koagulasi intrinsik serta mengikat dan mengaktifkan platelet sehingga memperkuat pembentukan bekuan darah. Trombin juga mengaktivasi sel endotel melalui reseptor proteaseactivated receptors (PAR), sehingga terjadi pelepasan C5A yang menyebabkan monosit melepas sitokin serta pembentukan trombin melalui peningkatan ekspresi tissue factor. Selanjutnya sitokin akan mengaktifkan sistem inflamasi, sedangkan trombin menyebabkan terjadinya fibrin. ${ }^{13,14}$ Mekanisme proses hiperkoagulasi pada pasien COVID-19 dapat dilihat pada Gambar 3. 


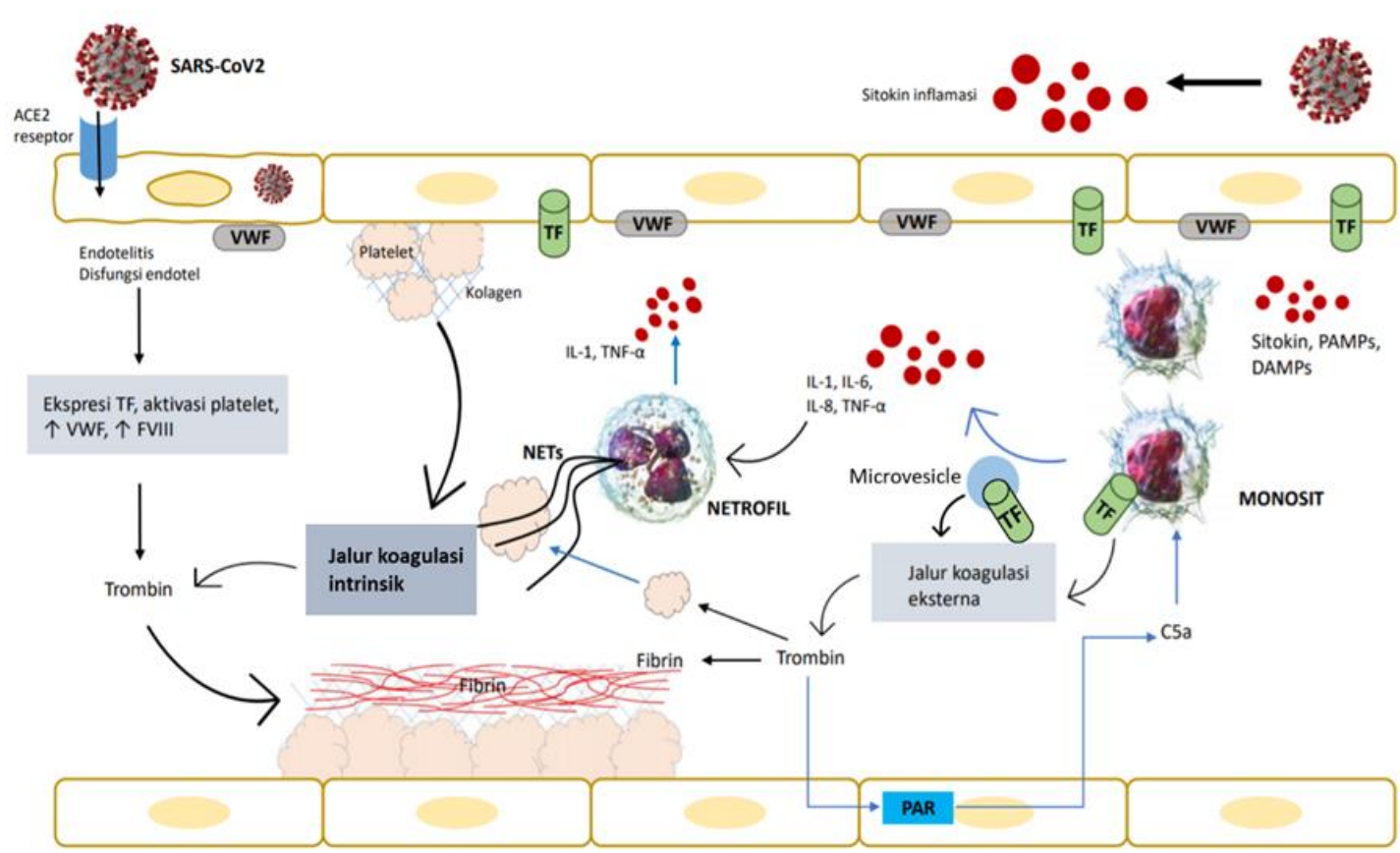

Gambar 3. Patofisiologi hiperkoagulasi pada pasien COVID-19 ${ }^{14,15}$. Hipotesis saat ini tentang hiperkoagulasi pada pasien COVID-19 berhubungan dengan saling keterkaitan antara penyebab inflamasi (panah biru) dan trombosis (panah hitam). SARS-CoV-2 yang berasal dari alveoli menyebabkan respons inflamasi yang berlebihan. Pelepasan sitokin inflamasi menyebabkan aktivasi sel epitel, monosit dan makrofag. Stimulus pro-inflamasi yang bersirkulasi, seperti viral pathogen associated molecular patterns (PAMPs), damage-associated molecular patterns (DAMPs) dan sitokin akan mengaktivasi monosit, yang direspons dengan terpicunya ekspresi tissue factor membran. Kerusakan endotel oleh virus juga menyebabkan paparan tissue factor di sel endotel. Monosit yang teraktivasi akan direkrut ke sel endotel. Ekspresi tissue factor di monosit aktif, mikrovesikel berasal dari monosit dan sel endotel akan mengaktivasi jalur koagulasi ekstrinsik, menyebabkan endapan fibrin dan bekuan darah. Infeksi virus secara langsung di sel endotel melalui resptor ACE2 menyebabkan aktivasi dan disfungsi endotel, ekspresi tissue factor, aktivasi platelet serta peningkatan kadar VWF dan FVIII, yang semuanya berkontribusi dalam pembentukan trombin dan bekuan fibrin. Trombin akan menyebabkan inflamasi melalui efeknya di platelet, bersama sel endotel yang mengaktivasi netrofil akan menyebabkan pelepasan NETs dari netrofil. NETs akan mengaktivasi jalur koagulasi intrinsik serta mengikat dan mengaktifkan platelet untuk membentuk bekuan darah. Trombin juga mengaktivasi endotel melalui reseptor PAR, mengakibatkan pelepasan C5A yang akan mengaktivasi monosit.

Sebagian besar pasien COVID-19 mengalami peningkatan kadar D-dimer. Peningkatan kadar D-dimer ini berhubungan dengan prognosis yang lebih buruk dan mortalitas yang lebih tinggi. Perera dkk, melakukan penelitian retrospektif mengenai hubungan antara peningkatan kadar D-dimer dengan kejadian trombosis paru dengan menggunakan pemeriksaan $C T$ pulmonary angiography (CTPA). Mereka menyarankan bahwa kadar Ddimer > $2 \mathrm{mcg} / \mathrm{ml}$ memiliki risiko terjadinya komplikasi trombosis paru sehingga perlu dipertimbangkan untuk melakukan pemeriksaan CTPA. ${ }^{16}$ Namun demikian, kasus emboli paru berat dengan hasil pemeriksaan D-dimer 
negatif, pernah dilaporkan. ${ }^{17} \mathrm{Yu} \mathrm{B}$ dkk menyarankan, pemberian antikoagulan tidak hanya berdasarkan kadar D-dimer saja. Sistem penilaian prediksi terjadinya tromboemboli vena mungkin lebih berguna dibandingkan jika hanya berpatokan pada kadar D-dimer saja. ${ }^{18}$

Walaupun dengan peningkatan D-dimer yang tidak begitu tinggi, kami melaporkan kecurigaan komplikasi tromboemboli pada pasien COVID-19 yang kami rawat. Kecurigaan emboli paru pada pasien kami berdasarkan gejala klinis yang terjadi. Gejala klinis emboli paru umumnya berupa dispnea/takipnea, takikardi, sianosis, nyeri dada, batuk, hemoptisis, wheezing dan orthopnea. Onset gejala klinis tersebut berlangsung akut. Berdasarkan keparahan dari gejala klinisnya, emboli paru akut dapat dibagi dalam 3 kategori: masif, sub-masif dan risiko rendah. Pada emboli paru akut masif, gejala klinis disertai dengan hipotensi, hipoperfusi, arritmia, kejang hingga kematian. Sedangkan emboli paru sub-masif, tekanan darah pasien dapat normal tetapi terdapat bukti adanya disfungsi ventrikel kanan. Namun, tanda dan gejala klinis tersebut hanya mengarahkan pada kecurigaan adanya emboli paru akut. Sensitifitas dan spesifisitasnya tidak cukup untuk menegakkan diagnosis emboli paru akut. ${ }^{19}$

Pemeriksaan ronsen toraks tidak dapat digunakan untuk menegakkan diagnosis emboli paru, namun gambaran khas emboli paru terkadang dapat ditemukan. Beberapa tanda khas yang dapat ditemukan dari ronsen toraks berupa Palla's sign, Westermark sign dan Hampton's hump. Evaluasi ronsen toraks pada kasus kami, terdapat tanda Hampton's hump di paru kanan. Tanda ini memiliki gambaran opasitas yang melekat pada pleura berbentuk baji dengan puncak cembung bulat mengarah ke hilum. Gambaran ini timbul akibat adanya nekrosis alveolar dan perdarahan. Hampton's hump memiliki angka spesifisitas yang tinggi (82\%) namun sensitifitasnya rendah $(21 \%)$. Sehingga membatasi kegunaannya dalam menegakkan diagnosis emboli paru. Tanda Hampton's hump juga memiliki karakteristik yang sama dengan konsolidasi paru akibat pneumonia. ${ }^{20}$

European Society of Cardiology (ESC) menganjurkan pemeriksaan CTPA sebagai panduan untuk menegakkan diagnosis emboli paru akut. $^{21}$ Pemeriksaan CTPA memiliki nilai sensitifitas $81 \%$ dan spesifisitas hingga $100 \% .^{20}$ Pada kasus kami, pemeriksaan CTPA tidak dapat dilakukan.

Kecurigaan terjadinya emboli paru akut juga dapat dinilai dengan pemeriksaan EKG. Gambaran EKG yang terlihat merepresentasikan adanya regangan dan dilatasi ventrikel kanan. Emboli paru akut akan memediasi pelepasan tromboxane A2 dan serotonin yang mengakibatkan peningkatan tahanan vaskular paru. Peningkatan tahanan vaskular paru yang mendadak ini menyebabkan dilatasi ventrikel kanan dan pemanjangan waktu kontraksi. ${ }^{21}$ Sehingga, gambaran EKG pada emboli paru berupa takikardi, pola S1Q3T3 atau inversi gelombang $\mathrm{T}$ anteroseptal dan pemanjangan interval QT. Inversi gelombang $\mathrm{T}$ anteroseptal menunjukkan tekanan pada arteri pulmonal > 30 $\mathrm{mmHg}$. Pemanjangan interval QT pada emboli paru akut bersifat reversible. ${ }^{19,22}$ Namun, Matshusita dkk, mengatakan penilaian emboli paru berdasarkan perubahan pada lead III dan V1-V4 kurang sensitif dikarenakan sindroma koroner akut memiliki gambaran EKG yang serupa. Matshusita dkk, menyarankan penilaian emboli paru 
melalui perhitungan gel $Q T$ difference lebih dari $20 \mathrm{~ms}$ dan $Q T$ correction di lead V1-V6. Peningkatan gel QTc diatas normal, menandakan adanya risiko terjadinya emboli paru akut. ${ }^{23}$ Penelitian retrospective yang dilakukan Buppajarntham dkk, pada 300 pasien emboli paru akut didapatkan, pemanjangan interval QT menunjukkan adanya peningkatan dilatasi ventrikel kanan dan disfungsi sitolik, kebutuhan waktu perawatan yang lebih lama dan episode hipotensi yang lebih sering. ${ }^{24}$ Pada kasus kami, sebelum kecurigaan terjadi komplikasi emboli paru, gambaran EKG pasien tidak menampakkan pola S1Q3T3 dan pemanjangan interval QTc.

Dalam kasus ini, pasien juga menunjukkan gangguan pada cerebrovaskular berupa hemiparese kiri. Kami tidak dapat menyingkirkan penyebab dari kelemahan ini dengan pemeriksaan CT-Scan, dikarenakan fasilitas yang tidak memungkinkan. Dalam satu penelitian observasional, komplikasi neurologi yang dapat terjadi pada pasien COVID-19, salah satunya adalah stroke $(85 \%)$ yang merupakan bentuk penyakit cerebrovaskular dimana kasusnya dapat berupa trombosis pada sinus vena serebral serta perdarahan intraserebral. Kasus baru yang ditemukan pada pasien COVID-19 ratarata memiliki riwayat penyakit sebelumnya seperti usia tua ( $>65$ th), hipertensi, riwayat merokok, dan kadar gula darah yang tinggi. Sebagai tambahan, menurut panduan American Thoracic Asossiation, pasien pneumonia COVID-19 derajat kritis akan mengalami komplikasi cerebrovaskular. ${ }^{25}$. Adanya hemiparese kiri pada pasien ini memperkuat dugaan terjadinya komplikasi tromboemboli pada pasien kami.
Prinsip penanganan emboli paru adalah terapi supportive, mencegah terjadinya bekuan dan penatalaksanaan syok obstruksi. Pemberian antikoagulan merupakan pilihan terapi emboli paru. ${ }^{21}$ Di ICU, penggunaan UFH lebih direkomendasikan karena dosis adekuat intravena dapat tercapai dengan pemantauan aPTT. Dosis UFH yang digunakan adalah $80 \mathrm{IU} / \mathrm{kg}$ dilanjutkan dengan $18 \mathrm{IU} / \mathrm{kg} / \mathrm{jam}$ dengan target aPTT tidak lebih dari 80 detik. Pada pasien dengan kondisi yang tidak stabil, UFH juga lebih terpilih karena dosis dengan mudah dapat disesuaikan, dan jika pemberian trombolitik diperlukan, UFH memiliki efek yang lebih singkat dibanding LMWH. ${ }^{19}$

Komplikasi yang dapat terjadi akibat terapi antikoagulan adalah perdarahan dan trombositopenia yang dipicu oleh heparin. Hal ini mungkin berhubungan dengan tromboemboli vena dan arteri, dan harus dicurigai jika terdapat penurunan trombosit lebih 50\% dari nilai awal atau adanya kejadian tromboemboli baru saat terapi heparin masih diberikan. Pasien yang mendapat terapi heparin selama lebih dari 4 hari, atau pernah terpapar terapi heparin sebelumnya, termasuk dalam pasien yang memiliki risiko terjadinya trombositopenia yang dipicu oleh heparin. Pemantauan secara serial nilai haemoglobin, trombosit, aPTT harus dilakukan selama terapi antikoagulan diberikan. ${ }^{19}$

Pemberian trombolitik direkomendasikan pada kasus emboli paru masif. Trombolitik akan mengaktivasi plasminogen menjadi plasmin sehingga akan mempercepat proses lisis dari trombus. Pilihan agen trombolitik yang dapat digunakan yaitu alteplase (recombinant tissue plasminogen activator/rtPA) dan streptokinase. Di Amerika, food and drug administration 
hanya menganjurkan penggunaan rtPA untuk penanganan emboli paru. ${ }^{26}$ Wang dkk, melaporkan pemberian tPA pada 3 pasien COVID-19 yang terventilasi mekanik dan hemodinamik ditopang dengan vasopressor. Ketiga kasus menunjukkan perbaikan $P / F$ ratio di awal pemberian tPA, namun 2 kasus menunjukkan perbaikan $P / F$ ratio yang sementara lalu kembali mengalami perburukan setelah pemberian tPA selesai. ${ }^{27}$

Penggunaan trombolitik berhubungan dengan risiko terjadinya perdarahan spontan dan intracranial haemorrhage sehingga pemberian trombolitik harus dipertimbangkan secara hati-hati. American College of Chest Physician (CHEST) merekomendasikan penggunaan trombolitik pada pasien COVID-19 yang mengalami emboli baru bila disertai dengan klinis perburukan sistem kardiovaskular, disfungsi ventrikel kanan yang progresif, dan peningkatan kadar biomarker jantung. ${ }^{10}$

Karena tingginya risiko komplikasi tromboemboli pada pasien COVID-19, dalam penanganannya perlu memperhatikan faktor risiko serta strategi yang optimal untuk profilaksis dan terapi komplikasi tromboemboli. Beberapa penelitian menyarankan untuk mempertimbangkan penggunaan dosis antikoagulan yang lebih besar sebagai pencegahan komplikasi tromboemboli. $^{3,11,12}$

\section{KESIMPULAN}

Peningkatan D-dimer pada pasien COVID-19 sangat dinamis dan berhubungan dengan risiko terjadinya komplikasi tromboemboli. Kadar Ddimer yang rendah tidak dapat menjadi prediksi negatif risiko komplikasi tromboemboli pada pasien COVID-19. Diperlukan strategi penapisan yang baik untuk menentukan risiko komplikasi tromboemboli pada pasien COVID-19. Di antaranya berupa penggunaan sistem penilaian prediksi PADUA dan evaluasi EKG secara rutin. Jika memungkinkan, pemeriksaan CTPA dapat dilakukan untuk menegakkan diagnosis dan sebagai deteksi dini terjadinya komplikasi emboli paru pada pasien COVID-19. Pada pasien COVID-19 yang dirawat di ICU dengan kondisi kritis, perlu dipertimbangkan pemberian terapi antikoagulan yang lebih agresif dan penggunaan dosis terapeutik, mengingat banyaknya kasus komplikasi tromboemboli walaupun telah mendapatkan dosis profilaksis.

\section{DAFTAR PUSTAKA}

1. Cucinotta D, Vanelli M. WHO declares COVID-19 a pandemic. Acta Biomed. 2020;91(1):157-160. doi:10.23750/abm.v91i1.9397

2. Lodigiani C, Iapichino G, Carenzo L, et al. Jo ur $1 \mathrm{P}$ of. Thromb Res. Published online 2020. doi:10.1016/j.thromres.2020.04.024

3. Helms J, Tacquard C, Severac F, et al. High risk of thrombosis in patients with severe SARS - CoV - 2 infection: a multicenter prospective cohort study. Intensive Care Med. Published online 2020. doi:10.1007/s00134-020-06062-x

4. Kollias A, Kyriakoulis KG, Dimakakos E, Poulakou G, Stergiou GS, Syrigos K. Thromboembolic risk and anticoagulant therapy in COVID-19 patients: emerging evidence and call for action. $\mathrm{Br} J$ Haematol. 2020;189(5):846-847. doi:10.1111/bjh.16727

5. Greenberg CS. Advances in hematology. 2017;15(8):580-583. 
6. Guan W, Ni Z, Hu Y, et al. Clinical characteristics of coronavirus disease 2019 in China. $N$ Engl $J$ Med. 2020;382(18):1708-1720. doi:10.1056/NEJMoa2002032

7. Zhou F, Yu T, Du R, et al. Clinical course and risk factors for mortality of adult inpatients with COVID-19 in Wuhan, China: a retrospective cohort study. Lancet. 2020;395(10229):1054-1062. doi:10.1016/S0140-6736(20)305663

8. Moore MP. d-Dimer testing for the exclusion of venous thromboembolism in pregnancy. Intern Med J. 2018;48(8):1013. doi:10.1111/imj.13978

9. Zhai Z, Li C, Chen Y, et al. Prevention and Treatment of Venous Thromboembolism Associated with Coronavirus Disease 2019 Infection: A Consensus Statement before Guidelines. Thromb Haemost. 2020;120(6):937-948. doi:10.1055/s-0040-1710019

10. Moores LK, Tritschler T, Brosnahan $\mathrm{S}$, et al. Prevention, Diagnosis, and Treatment of VTE in Patients With Coronavirus Disease 2019. Chest. 2020;(June). doi:10.1016/j.chest.2020.05.559

11. Llitjos JF, Leclerc M, Chochois C, et al. High incidence of venous thromboembolic events in anticoagulated severe COVID-19 patients. $J$ Thromb Haemost. 2020;18(7):1743-1746. doi:10.1111/jth.14869

12. Klok FA, Kruip MJHA, Meer NJM Van Der, et al. Incidence of thrombotic complications in critically ill ICU patients with COVID-19. Thromb Res. 2020;191(April):145-147. doi:10.1016/j.thromres.2020.04.013

13. Abou-Ismail MY, Diamond A, Kapoor S, Arafah Y, Nayak L. The hypercoagulable state in COVID19: Incidence, pathophysiology, and management. Thromb Res. 2020;194:101-115. doi:10.1016/j.thromres.2020.06.029

14. Hajra A, Mathai SV, Ball S, et al. Management of Thrombotic Complications in COVID-19: An Update. Drugs. 2020;(0123456789). doi:10.1007/s40265-020-01377-x

15. Merad M, Martin JC. Pathological inflammation in patients with COVID-19: a key role for monocytes and macrophages. Nat Rev Immunol. 2020;20(June):355362. doi:10.1038/s41577-020-03314

16. Perera A, Chowdary P, Johnson J, Lamb L, Drebes A, Mir N, Sood T. Elevated D-dimers Useful Prediction of Pulmonary Artery Thrombosis in COVID-19 Patients at Initial Presentation to Hospital [abstract]. Res Pract Thromb Haemost. 2020; 4 (Suppl 1). https:// 2020. No Title.

17. Hilal Dagkiran, Riza Atas, Ivana Tomic, Claudia Plachtzik, MD, Tobias Geisler, MD, Meinrad P Gawaz, MD, Martin Oberhoff, MD, Thomas Anger M. Severe Pulmonary Embolism with Negative D-Dimer-Testing. J Cardiol Ther. 2015;2(1):265-268. doi:10.6051/j.issn.23096861.2015.02.66

18. Yu B, Li X, Chen J, et al. Evaluation of variation in $\mathrm{D}$ - dimer levels among COVID - 19 and bacterial pneumonia: a retrospective analysis. J Thromb Thrombolysis. 2020;2(December 2019). doi:10.1007/s11239-020-02171-y 
19. Marshall PS, Mathews KS, Siegel MD. Diagnosis and management of life-threatening pulmonary embolism. J Intensive Care Med. 2011;26(5):275-294. doi:10.1177/0885066610392658

20. Shawn TH, Yan L, Lateef F. The chest $\mathrm{X}$ ray in pulmonary embolism: Westermark sign, Hampton's Hump and Palla's sign. What's the difference? $J$ Acute Dis. 2018;7(3):99. doi:10.4103/22216189.236822

21. Konstantinides S V., Meyer G, Bueno H, et al. 2019 ESC Guidelines for the diagnosis and management of acute pulmonary embolism developed in collaboration with the European respiratory society (ERS). Eur Heart J. 2020;41(4):543-603. doi:10.1093/eurheartj/ehz405

22. Nadrous HF, Olson EJ, Douglas WW, Decker PA, Nadrous JH. Cryptic Septic Shock: A Subanalysis of Early , Goal-Directed Therapy. Chest. 2014;124(October 2003):1090850.

doi:10.1378/chest.124.4
23. Matsushita K, Marchandot B, Jesel L, Ohlmann P, Morel O. Impact of COVID-19 on the Cardiovascular System: A Review. J Clin Med. 2020;9(5):1407. doi: $10.3390 /$ jcm 9051407

24. Buppajarntham S, Seetha Rammohan HR, Junpaparp P, Figueredo VM. Prognostic value of prolonged QTc interval in patients with acute pulmonary embolism. Acta Cardiol. 2014;69(5):550-555. doi:10.1080/ac.69.5.3044882

25. Reddy ST, Garg T, Shah C, et al. Cerebrovascular Disease in Patients with COVID-19: A Review of the Literature and Case Series. Case Rep Neurol. $\quad$ 2020;77030:199-209. doi:10.1159/000508958

26. Busse LW, Vourlekis JS. Submassive pulmonary embolism. Crit Care Clin. 2014;30(3):447-473. doi:10.1016/j.ccc.2014.03.006

27. Wang J, Hajizadeh N, Moore EE, et al. Tissue plasminogen activator (tPA) treatment for COVID-19 associated acute respiratory distress syndrome (ARDS): A case series. $J$ Thromb Haemost. 2020;18(7):17521755. doi:10.1111/jth. 14828 